\title{
Electrochemical Synthesis of Peptides Mediated by Triphenylphosphine
}

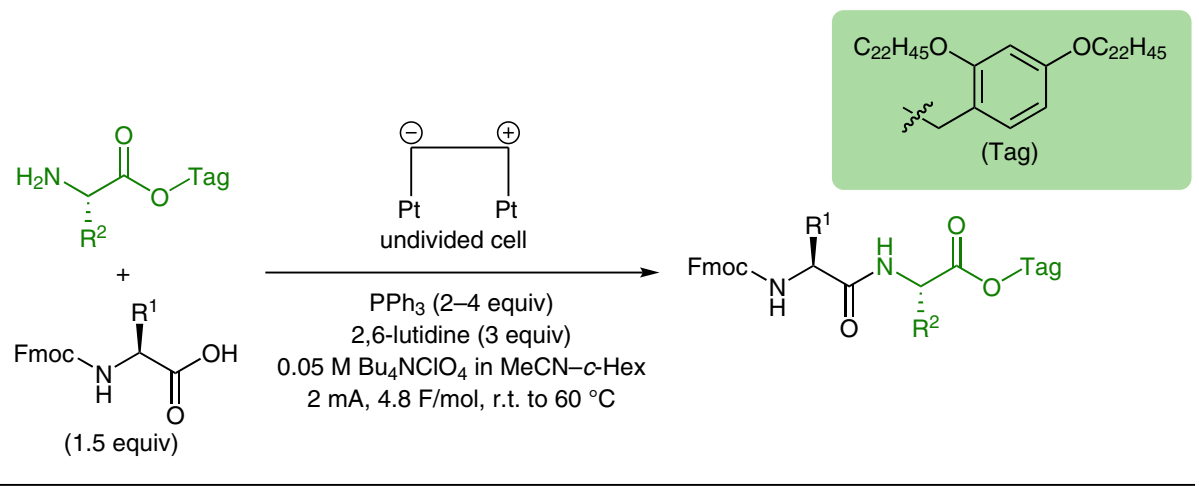

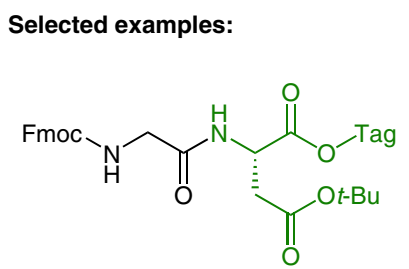

$98 \%$ yield<smiles></smiles>

$99 \%$ yield<smiles>CCOC(=O)CC(NC(=O)OCC(F)(F)F)C(=O)O[Ga]</smiles>

$98 \%$ yield<smiles>CCCCOC(=O)C[C@H](NC(=O)C(NC(F)F)C(C)C)C(=O)OCCCC</smiles>

$98 \%$ yield

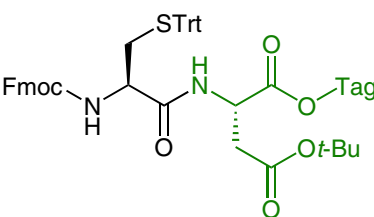

$95 \%$ yield

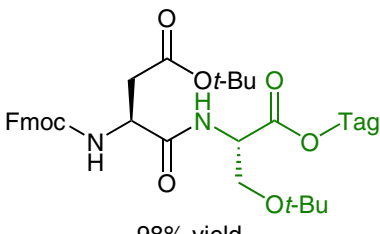

$98 \%$ yield

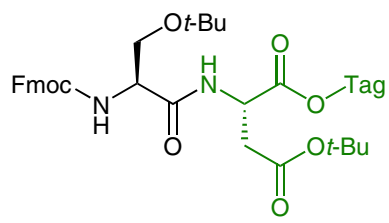

$98 \%$ yield

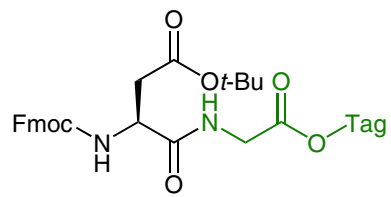

$97 \%$ yield

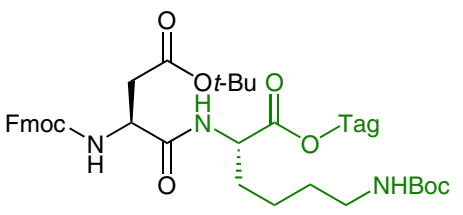

$98 \%$ yield

\section{Category}

Peptide Chemistry

\section{Key words}

electrochemistry

peptide coupling

triphenylphosphine

soluble tags

\section{Syniact Month}

Significance: Peptides have been attracted increasing attention in the discovery of new drugs. The authors have developed an electrochemical peptide-bond forming reaction that proceeds in a biphasic system that minimizes waste derived from coupling reagents.
Comment: Anodic oxidation of $\mathrm{Ph}_{3} \mathrm{P}$ generates a radical cation that serves as the coupling reagent by activating the carboxylic acid. The $\mathrm{Ph}_{3} \mathrm{P}=\mathrm{O}$ byproduct can be recovered and recycled. This triphenylphosphine-mediated peptide-bond-formation reaction under electrochemical conditions gave a variety of peptides in excellent yields. 